\title{
EFFECTIVENESS OF THE PIGEON POX VACCINE ON THE CHICKEN VACCINATED WITH AVIAN INFLUENZA VACCINE
}

\author{
Christine A. Mikhael ${ }^{* 1}$ and Nada, A. Fathy ${ }^{2}$ \\ ${ }^{1}$ Central Laboratory for Evaluation of Veterinary Biologics, Abbasia, Cairo, Egypt \\ ${ }^{2}$ Veterinary Serum and Vaccine Research Institute, Abbasia, Cairo, Egypt \\ * Corresponding author: Christine A. Mikhael; email; christaziz@gmail.com
}

\begin{abstract}
Evaluation of the effectiveness of pigeon pox (PP) vaccine in improvement the required immunity to avian influenza (AI) virus vaccine in birds and reducing its shedding after challenge was the object of this study.Specific pathogen free chicks were vaccinated with PP and AI in 10 groups at 5 and/or 8 days of age and/or boosted after 35 days then challenged after 28 days with virulent highly pathogenic AI virus local Egyptian field isolate. The development of immune responses to AI haemagglutinine was recorded and also AI virus shedding after challenge.Vaccinated 10 groups induced protective immune responses; especially in the groups which were boosterly vaccinated with PP vaccine. All birds vaccinated and experimentally challenged 28 days later were protected against virulent AI (H5N1); mild clinical signs of infection developed in few number of vaccinated birds. In contrast, all unvaccinated birds died within 72 hours of challenge. Vaccination of chicks with PP and AI vaccines provided good effectiveness of the PP vaccine on the immune response of vaccinated birds with AI vaccine and showed decreasing in shedding after challenge; especially in the groups which take a booster vaccination of PP and AI vaccine. Although eradication still remain the $1^{\text {st }}$ of choice for controlling the AI in the circumstances of a continuing and wide spread outbreak, but also the availability of new designing future vaccination regime by using avipox virus vaccine should be applied.
\end{abstract}

Original Article:

https://dx.doi.org/10.21608/j avs.2019.62659

Received 03 September, 2019 Accepted 08 Ocober, 2019. Published in October, 2019.

This is an open access article under the term of the Creative Commons Attribution 4.0 (CCBY) International License . To view a copy of this license, visit http://creativecommons.org/lice $\underline{\text { nses/by/4.0/ }}$

Keywords: Avian influenza, Chickens, prim-boost, pigeon pox vaccines, shedding.

\section{INTRODUCTION}

The threat that highly pathogenic avian influenza (HPAI) virus, a virus subtype H5N1 threaten to poultry and public health has intensified (ChuangLing et al., 2003). As the virus become established in poultry in developing countries, the number of human cases increases (Qiao et al., 2003 and OIE 2019). Vaccination is a useful tool to control avian influenza (AI) especially when biosecurity and stamping out strategies alone are not successfully implemented (Qiao et al., 2003 and WHO 2008).

In late 2016, the epidemiology of avian influenza (AI) in Egypt was exhibited a substantial change due to the emergence of HP H5N8 in wild birds. (Selimet al., 2017). An immunization strategy depending on using bivalent and multivalent vaccines containing whole inactivated viruses has been advocated before to control several avian pathogens
(Lee et al., 2013). Tripathy and Reed (2003)and Weli and Tryland(2011)reported that prophylaxis can be achieved by vaccination, live fowlpox virus or pigeon pox virus for vaccination against avipox viruses. These vaccines are very effective and have undoubtedly contributed immensely to the prevention of the disease in commercial poultry farming.

Pigeon pox (PP) virus produces mild infection in chicken and turkey but it is more pathogenic for pigeons (Bossinger et al., 1982). For this reasons, PP vaccine is used not only for vaccination of pigeons but also against pox infection in chickens and turkeys (Gottstein et al., 2004 and Wang et al., 2006).

Vaccines of fowl pox or pigeon pox virus origin have been routinely used for more than half a century to prevent fowl pox in commercial poultry in endemic areas (Siddique et al., 2011), or has been diagnosed in previous flocks (OIE 2019). 
Pigeon pox vaccine appears to provide better cross protection to some wet pox field strains. The combination of fowl pox and pigeon pox stimulates a broader spectrum immune response needed for optimum protection (Hy-Line, 2019). Poxviruses, encode multiple classes of immunomodulatory proteins that have evolved specifically to inhibit such diverse processes as apoptosis, the production of interferons, chemokines, and inflammatory cytokines, and the activity of cytotoxic $\mathrm{T}$ lymphocytes (CTLs), natural killer (NK) cells, complement, and antibodies. Often, the evolutionary origins of these virus-encoded immunomodulatory proteins are difficult to trace (Johnston and Grant, 2003 and Meseko et al., 2012).

Attenuated avipox viruses (APVs) have been employed as vaccines for chickensor as nominate vectors for the delivery of recombinant proteinsin both mammalian and avian species (Taylor et al. 1988 and Paoletti, 1990). Elicit T helper 1 (Th1) and $\mathrm{CD}_{8} \mathrm{~T}$-cell and resulted in the induction of antibodyand cellmediated responses (Radaelli, et al. 2003), led to the induction of gamma interferon (IFN) in spleen shown promising results.For instance, Websteret al. (2005) reported that a prime-boost vaccination regimen, which included FPV could confer protection against challenge.

An in vivo study also it was conducted to further examine host responses to Avipox viruses. Cellular responses were characterizedby a slight, although statistically significant, increase in thepercentage of $\mathrm{CD}_{4}$ cells and a decrease in the percentage ofCD 8 cells among spleen cells at 1 day post inoculation and also utilize IL-10 as a mechanism to evade the host immune system (Diener et al., 2008).

Avipox viruses induced immunity in vaccinated host which, with the most immunogenic antigens, was protective when use as recorded in Beard, et al. (1991), Taylor, et al. (1991 and 1992), Webster, et al. (1996) and Giotis and Skinner, (2019) who used it as a recombinant vaccine vector.The current study aimed to evaluate the effect of pigeon pox virus vaccine efficacy to improve the avian influenza virus vaccine immune response in chicken and reduce its shedding after experimental infection.

\section{MATERIALS AND METHODS}

\section{Experimental chicks}

Six hundred (600) one day old, specific pathogen free (SPF) chicks were obtained from the SPF Egg Production Farm, Koum Oshein, El-Fayoum, Egypt. All birds were housed in separated negative pressure filtered air isolators and were provided with autoclaved commercial water and feed. The chicks were used for evaluation of the tested vaccination programs.

\section{Vaccines}

1. Pigeon pox virus vaccine: The Hungarian strain of pigeon pox virus in freeze dried form was used for vaccination of the chicks. Its $\mathrm{EID}_{50}$ was found to be $10^{7} / \mathrm{ml}$. Itwas obtained from the Veterinary Serum and Vaccine Research Institute (VSVRI), Cairo.

2. Avian influenza virus vaccine: The vaccine viruses used in this study include the reassortant AIH5N1 viruses, 2016 (H5N1) from the Veterinary Serum and Vaccine Research Institute, Cairo.

\section{Viral strains}

1. Fowl pox virus strain: The Beaudette strain of fowl pox virus was used for SNT. Its $\mathrm{EID}_{50}$ was found to be $10^{9} / \mathrm{ml}$. It was kindly obtained from the Veterinary Serum and Vaccine Research Institute, Cairo.

\section{Avian influenza virus}

It was used as antigens to detect antibodies against H5N1 viruses for vaccinated birds with $10^{6}$ $\mathrm{EID}_{50} / 100 \mu \mathrm{l}$ of highly pathogenic avian influenza (HPAI).Virus.H5N1 A/chicken/Egypt/D10552B/201 5 (H5N1) viruses were used

\section{Challenge virus}

1.Local Egyptian HPAI (2015) field isolate Obtained from Newcastle Disease department, VSVRI; and used for challenge. Its titer was $10^{10}$ $\mathrm{EID}_{50} / \mathrm{ml}$. It was submitted by National Laboratory for Quality control of Poultry (NLQP), Dokky, Egypt. Challenge test was done according to OIE (2017).

2.Fowl pox virus: Having a titer of $10^{6} \mathrm{EID}_{50} / \mathrm{ml}$ from the VSVRI, Cairo.

\section{Serum Samples}

Serum samples were collected weekly from vaccinated chicks on different intervals before and after vaccination on weekly intervals for 5 months, and stored at $-20^{\circ} \mathrm{C}$ till application of Heamagglutination test (HI) and Serum Neutralization Test (SNT).

\section{Swapping for avian influenza shedding detection}

Twenty birds from each group were randomly removed from all sites, placed in BSL-3 certified isolators and infected with challenge virus. Challenge was carried out at 28 days post vaccination (DPV) using HPAI virus at a dose $10^{6} \mathrm{EID}_{50} / 0.1$ via the natural route Birds were then monitored daily for morbidity and mortality. Oral swabs were obtained from each bird at days 2, 5, and 7 post infections for virus titration in eggs. The challenge dose was according to the standard dose being used in Egypt to evaluate all HPAI-H5 submitted to the Central Laboratory for Evaluation of Veterinary Biologics, Egypt. 


\section{Effectiveness Of The Pigeon Pox Vaccine ......}

Oropharengial swabs were collected from all challenged birds in $1 \mathrm{ml}$ of sterile phosphate buffer saline at 2,5, and 7days post AI challenge to monitor virus shedding titers. Swab samples were vortexed and centrifuged at $2000 \mathrm{rpm}$ for $10 \mathrm{~min}$ at $4^{\circ} \mathrm{C}$. Supernatants were used for virus titration in 10 days old SPF embryonated chicken eggs, according to Tumpey et al., (2004) and EID50/ml was calculated according to Reed and Munech (1938). Then each swab was examined using individually HA plate was carried out according to (OIE 2018).

\section{Serological tests}

\section{Serum Neutralization Test (SNT):}

All collected sera were screened against avipox according to the method described by OIE (2012).
The neutralization index (NI) was calculated according to Reed and Munech (1938).

- Heamagglutination test: All collected sera were screened against avian influenza according to the method described by Anon (1971) and OIE (2018).

- Heamagglutination Inhibition test (HI): All collected sera were screened against avian influenza antibody titer according to the method described by Allan et al., (1978).

\section{Experimental design}

Six Hundred chicks were divided into 10 groups (Each group contain 50 chicks, beside 100 chicks as control groups) as shown in table (1).

Table 1: Vaccination programs

\begin{tabular}{|c|c|c|c|}
\hline Group & Age & Vaccines & \multirow{29}{*}{$\begin{array}{l}\text { Pigeon Pox (PP) vaccine } \\
\text { was administered to } \\
\text { chickens by the wing-web } \\
\text { (WW) stab method with } \\
\text { single needle. } \\
\text { Avian influenza (AI) } \\
\text { vaccine was administrated } \\
\text { by intra-muscular injection }\end{array}$} \\
\hline 1 & 5 days & Pigeon pox & \\
\hline \multirow{3}{*}{2} & 5 days & Pigeon pox & \\
\hline & 8 days & Avian influenza & \\
\hline & \multicolumn{2}{|c|}{ Challenged with HPAI after 28 days } & \\
\hline \multirow{4}{*}{3} & 5 days & Pigeon pox & \\
\hline & 8 days & Avian influenza & \\
\hline & \multicolumn{2}{|c|}{ Boostered after 35 days with PP and AI } & \\
\hline & \multicolumn{2}{|c|}{ Challenged with HPAI after 28 days } & \\
\hline \multirow{3}{*}{4} & 5 days & Pigeon pox & \\
\hline & 8 days & $\mathrm{PP}$ and $\mathrm{AI}$ & \\
\hline & \multicolumn{2}{|c|}{ Challenged with HPAI after 28 days } & \\
\hline \multirow{4}{*}{5} & 5 days & Pigeon pox & \\
\hline & 8 days & $\mathrm{PP}$ and $\mathrm{AI}$ & \\
\hline & \multicolumn{2}{|c|}{ Boostered after 35 days with PP and AI } & \\
\hline & \multicolumn{2}{|c|}{ Challenged with HPAI after 28 days } & \\
\hline \multirow[t]{2}{*}{6} & 8 days & Avian influenza & \\
\hline & \multicolumn{2}{|c|}{ Challenged with HPAI after 28 days } & \\
\hline \multirow{3}{*}{7} & 8 days & Avian influenza & \\
\hline & \multicolumn{2}{|c|}{ Boostered after 35 days with AI } & \\
\hline & \multicolumn{2}{|c|}{ Challenged with HPAI after 28 days } & \\
\hline \multirow{3}{*}{8} & 8 days & Avian influenza & \\
\hline & \multicolumn{2}{|c|}{ Boostered after 35 days with PP and AI } & \\
\hline & \multicolumn{2}{|c|}{ Challenged with HPAI after 28 days } & \\
\hline \multirow[t]{2}{*}{9} & 8 days & $\mathrm{PP}$ and $\mathrm{AI}$ & \\
\hline & \multicolumn{2}{|c|}{ Challenged with HPAI after 28 days } & \\
\hline \multirow{3}{*}{10} & 8 days & $\mathrm{PP}$ and $\mathrm{AI}$ & \\
\hline & \multicolumn{2}{|c|}{ Boostered after 35 days with PP and AI } & \\
\hline & \multicolumn{2}{|c|}{ Challenged with HPAI after 28 days } & \\
\hline
\end{tabular}

HPAI: highly pathogenic Avian influenza.

Ten non-vaccinated control birds from the original groups were challenged with a fowl pox virus. The challenge virus was administered by the wingweb stab method in the opposite wing from that used for vaccination. Reactions were observed ten days post challenge. 


\section{RESULTS}

The vaccine has the ability to give good takes and immunity in chicks vaccinated with pigeon pox vaccine applied by the wing web stab method. Potency tests of pigeon pox virus vaccine were tested for potency in 5 day old and 35 day old birds.

Table 2: Average Body Weight (gm) in different vaccinated bird groups:

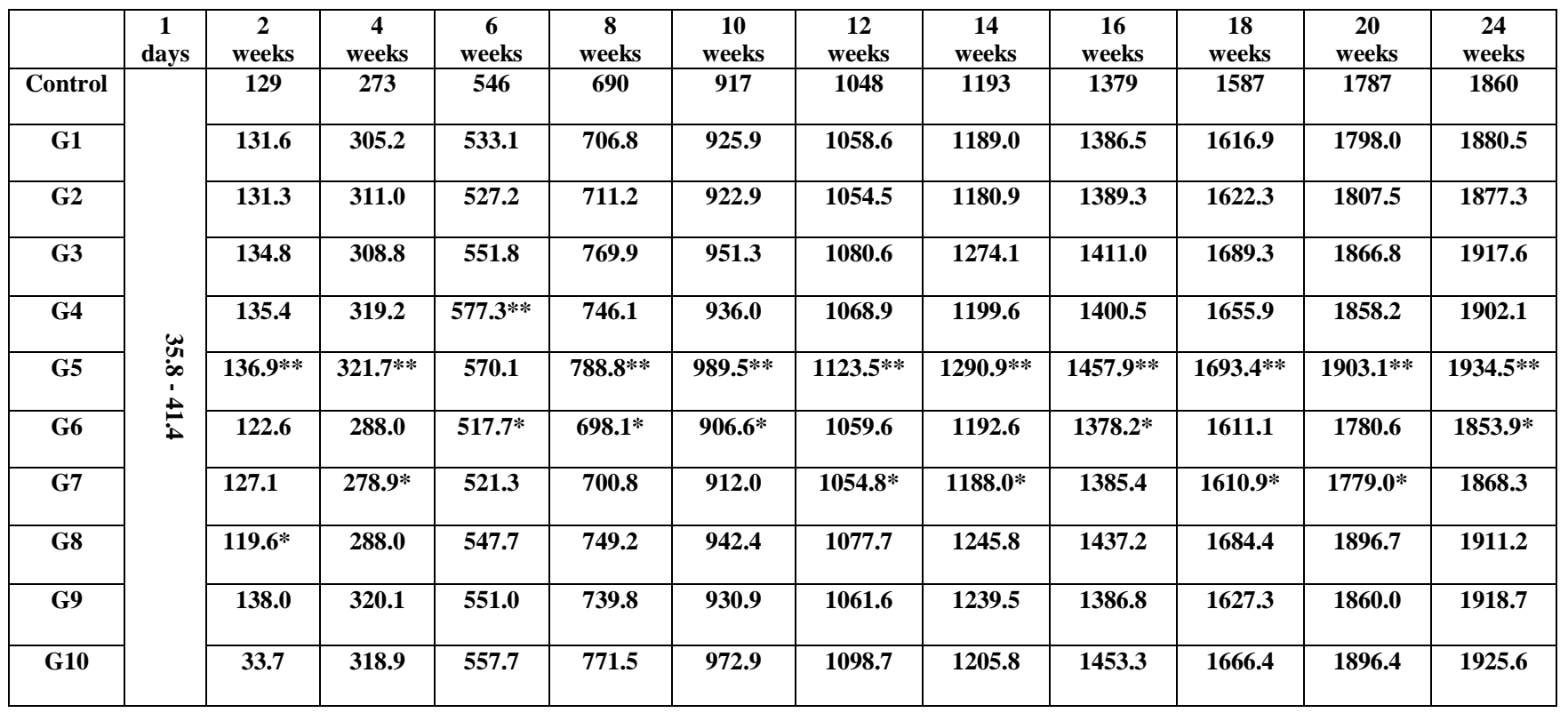

* : Lowest body weight within the same week.

**: Highest body weight within the same week.

Table 3: Immune response for PPV:Neutralizing index of different vaccinated bird groups: (SNT)

\begin{tabular}{|c|c|c|c|c|c|c|c|c|c|c|c|c|c|c|c|c|c|}
\hline Age & $\begin{array}{c}5 \\
\text { days }\end{array}$ & $\begin{array}{c}8 \\
\text { days }\end{array}$ & $\begin{array}{c}15 \\
\text { Days }\end{array}$ & $\begin{array}{c}21 \\
\text { days }\end{array}$ & $\begin{array}{c}28 \\
\text { days }\end{array}$ & $\begin{array}{c}35 \\
\text { days }\end{array}$ & $\begin{array}{c}42 \\
\text { days }\end{array}$ & $\begin{array}{c}48 \\
\text { days }\end{array}$ & $\begin{array}{c}55 \\
\text { days }\end{array}$ & $\begin{array}{c}8 \\
\text { weeks }\end{array}$ & $\begin{array}{c}10 \\
\text { weeks }\end{array}$ & $\begin{array}{c}12 \\
\text { weeks }\end{array}$ & $\begin{array}{c}14 \\
\text { weeks }\end{array}$ & $\begin{array}{c}16 \\
\text { weeks }\end{array}$ & $\begin{array}{c}18 \\
\text { weeks }\end{array}$ & $\begin{array}{c}20 \\
\text { weeks }\end{array}$ & 24 weeks \\
\hline G1 & 0.5 & 0.5 & 1.25 & 2.5 & 3.0 & 3.0 & 3.0 & 3.0 & 3.0 & 3.0 & 2.5 & 2.75 & 2.5 & 2.5 & 2.5 & 2.0 & 2.0 \\
\hline G2 & 0.5 & 0.5 & 1.0 & 2.5 & 3.0 & 2.75 & 2.75 & 3.0 & 3.0 & 3.0 & 3.0 & 2.5 & 2.5 & 2.5 & 2.5 & 2.25 & 2.25 \\
\hline G3 & 0.25 & 0.5 & 0.75 & 2.25 & 2.75 & 3.25 & 3.0 & 3.75 & 3.5 & 3.5 & 3.5 & 3.5 & 3.5 & 3.25 & 3.5 & 3.25 & 3.00 \\
\hline G4 & 0.5 & 0.5 & 1.75 & 2.75 & 3.0 & 3.0 & 3.75 & 3.75 & 3.75 & 3.75 & 3.75 & 3.75 & 3.25 & 3.75 & 3.5 & 3.5 & 3.25 \\
\hline G5 & 0.5 & 0.5 & 1.5 & 2.5 & 3.25 & 3.25 & 3.5 & 4.0 & 3.75 & 4.0 & 4.0 & 4.0 & 4.0 & 4.0 & 4.0 & 3.75 & 3.75 \\
\hline G6 & 0.25 & - & - & - & - & - & - & - & - & - & - & - & - & - & - & - & - \\
\hline G7 & 0.25 & - & - & - & - & - & - & - & - & - & - & - & & - & - & - & - \\
\hline G8 & 0.5 & - & - & - & - & - & - & 0.5 & 0.75 & 1.0 & 2.5 & 3.0 & 3.0 & 2.75 & 3.0 & 3.0 & 3.0 \\
\hline G9 & 0.25 & 0.25 & 1.5 & 2.75 & 3.0 & 3.0 & 3.5 & 3.75 & 3.75 & 3.75 & 3.75 & 3.75 & 3.25 & 3.55 & 3.5 & 3.5 & 3.25 \\
\hline G10 & 0.5 & 0.25 & 0.75 & 2.25 & 2.75 & 3.0 & 3.5 & 3.5 & 3.75 & 3.75 & 3.75 & 3.75 & 3.75 & 3.75 & 3.5 & 3.25 & 3.25 \\
\hline
\end{tabular}

G6 \& G7: Not none, they were not vaccinated against pox.

Neutralizing Index $(\mathrm{NI}) \geq 1.5$ is considered protective against pox viruses Cotral (1978). 


\section{Effectiveness Of The Pigeon Pox Vaccine ......}

Table 4: Mean HI antibody titers of avian influenza vaccine (HI) titer $\log _{2}$ in different vaccinated bird groups:

\begin{tabular}{|c|c|c|c|c|c|c|c|c|c|c|c|c|c|c|c|}
\hline & $\begin{array}{c}15 \\
\text { days }\end{array}$ & $\begin{array}{c}21 \\
\text { Days }\end{array}$ & $\begin{array}{c}28 \\
\text { days }\end{array}$ & $\begin{array}{c}35 \\
\text { days }\end{array}$ & $\begin{array}{c}42 \\
\text { days }\end{array}$ & $\begin{array}{c}48 \\
\text { days }\end{array}$ & $\begin{array}{c}55 \\
\text { Days }\end{array}$ & $\begin{array}{c}8 \\
\text { weeks }\end{array}$ & $\begin{array}{c}10 \\
\text { weeks }\end{array}$ & $\begin{array}{c}12 \\
\text { weeks }\end{array}$ & $\begin{array}{c}14 \\
\text { weeks }\end{array}$ & $\begin{array}{c}16 \\
\text { weeks }\end{array}$ & $\begin{array}{c}18 \\
\text { weeks }\end{array}$ & $\begin{array}{c}20 \\
\text { weeks }\end{array}$ & $\begin{array}{c}24 \\
\text { weeks }\end{array}$ \\
\hline G1 & - & - & - & - & - & - & - & - & - & - & - & - & - & - & - \\
\hline G2 & 8.5 & 9.8 & 10.8 & 10.3 & 9.8 & 9.5 & 9.5 & 9.5 & 9.5 & 9.0 & 9.0 & 9.0 & 9.0 & 9.0 & 9.0 \\
\hline G3 & 8.1 & 10.0 & 10.5 & 10.1 & 11.0 & 10.6 & 10.5 & 10.3 & 10.1 & 10.0 & 10.0 & 9.9 & 9.8 & 9.6 & 9.3 \\
\hline G4 & 8.9 & 10.0 & 11.0 & 11.0 & 11.0 & 11.0 & 11.0 & 11.0 & 10.0 & 10.0 & 10.0 & 9.9 & 9.8 & 9.6 & 9.0 \\
\hline G5 & 9.9 & 10.8 & 10.6 & 11.0 & 1.01 & 11.0 & 11.0 & 10.4 & 10.2 & 10.2 & 9.8 & 9.6 & 9.7 & 9.7 & 9.6 \\
\hline G6 & 8.3 & 9.8 & 10.6 & 10.0 & 10.0 & 9.8 & 9.5 & 9.2 & 9.3 & 9.0 & 9.0 & 9.0 & 9.0 & 9.0 & 9.0 \\
\hline G7 & 8.5 & 9.5 & 10.2 & 10.0 & 11.0 & 11.0 & 10.5 & 10.0 & 9.7 & 9.7 & 9.5 & 9.0 & 9.0 & 9.0 & 9.0 \\
\hline G8 & 8.4 & 10.0 & 10.5 & 10.0 & 11.0 & 11.0 & 10.8 & 10.5 & 10.3 & 9.7 & 9.3 & 9.3 & 9.0 & 9.0 & 9.0 \\
\hline G9 & 9.8 & 11.0 & 11.0 & 11.0 & 10.6 & 10.1 & 10 & 10 & 9.9 & 9.9 & 9.5 & 9.5 & 9.5 & 9.5 & 9.3 \\
\hline G10 & 9.6 & 11.0 & 11.0 & 11.0 & 10.3 & 10.8 & 10.8 & 10.6 & 10.0 & 10.0 & 10.0 & 10.0 & 10.0 & 9.5 & 9.5 \\
\hline
\end{tabular}

G1: Not none, it was not vaccinated against influenza.

HI titer considered protective if it is $2^{4}$ or more according to Allan et al. (1978).

\section{Avian Influenza shedding detection}

Table 5: Challenge virus shedding titers in vaccinated and non-vaccinated challenged control groups.

\begin{tabular}{|c|c|c|c|}
\hline \multirow{2}{*}{ Group } & \multicolumn{3}{|c|}{ Days post challenge } \\
\cline { 2 - 4 } & $2 \mathrm{dpc}$ & $5 \mathrm{dpc}$ & $7 \mathrm{dpc}$ \\
\hline Control & $3.6(4 / 5)$ & $\begin{array}{c}\text { Not } \\
\text { detected }\end{array}$ & $\begin{array}{c}\text { Not } \\
\text { detected }\end{array}$ \\
\hline 2 & 0.6 & 0.2 & 0 \\
\hline 3 & 0.6 & 0 & 0 \\
\hline 4 & 0.4 & 0 & 0 \\
\hline 5 & 0.2 & 0 & 0 \\
\hline 6 & 0.8 & 0.2 & 0 \\
\hline 7 & 0.8 & 0.2 & 0 \\
\hline 8 & 0.6 & 0 & 0 \\
\hline 9 & 0.4 & 0 & 0 \\
\hline 10 & 0.2 & 0 & 0 \\
\hline
\end{tabular}

-No reisolation virus was recovered from the oral swabs collected from chickens vaccinated with the experimental vaccine at 2,5and 7 post infection.

- All the titration of virus shedding by HA was less than 1 .

\section{Protection percent:}

Table 6: Result of Challenge test and protection percent

\begin{tabular}{|c|c|c|}
\hline Group & Animal protection & Protection \% \\
\hline Control & $0 / 20$ & $0 \%$ \\
\hline 2 & $17 / 20$ & $85 \%$ \\
\hline 3 & $18 / 20$ & $90 \%$ \\
\hline 4 & $19 / 20$ & $95 \%$ \\
\hline 5 & $19 / 20$ & $95 \%$ \\
\hline 6 & $17 / 20$ & $85 \%$ \\
\hline 7 & $18 / 20$ & $90 \%$ \\
\hline 8 & $18 / 20$ & $90 \%$ \\
\hline 9 & $18 / 20$ & $90 \%$ \\
\hline 10 & $19 / 20$ & $95 \%$ \\
\hline
\end{tabular}

Protection percent is $80 \%$ according to Egyption standard protocol (2017)

\section{DISCUSSION}

Countries such as Egypt in which H5N1 HPAI infection became endemic have not eradicated the infection by vaccination. This failure has many explanations, including the suboptimal use of vaccines that seems to have led to the emergence of new antigenic variants against which the classical vaccines are not fully protective. Maternal dependant 


\section{Christine A. Mikhael and Nada, A. Fathy}

antibodies(MDA) interference on vaccine efficacy likely contributes also to the lack of control by vaccination. The high MDA interference on inactivated vaccines and suggest that the use of a prime-boost strategy using avipox vector to prime may be able to overcome at least partially MDA interference(Richard-Mazet et al., 2014). In young chicks, their efficacy is optimal only at 2-3 weeks of age, and they cannot induce optimal protection in oneday-old birds (Michel et al.,2006).

Due to the bad effect of early investigation of fowlpox vaccine like retarded growth (Goldhaft, 1956), high mortality rate (Brandly and Dunlop 1939) and increased susceptibility to pullorum infection and infestation with coccidia, and according to these findings, vaccination of chicks of less than 30 days old was not recommended (Graham and Brandly 1940). Also Dalling (1933) recommended the use of pigeon pox virus vaccine instead of fowl pox virus to avoid the complications arising after using the fowl pox virus vaccine; and what founded by Taslima et al., (2008) which founded that maternally derived antibody from fowl pox vaccine until day 4 of age PPV vaccine is recommended for the prevention of fowl pox in chicks aged at day 1 to day 5. And also that recorded by Michael et al., (1986) that up till now fowlpox virus vaccine cannot be used for vaccination of baby chicks but only for chicken of not less than 2 months old.

So this study is a trial to use pigeon pox vaccine in young chicks according to that applied with BYC (2012) that said that the chicks may be vaccinated as young as one day of age by using the wing web method and using a one needle applicator. Tripathy and Reed (2008) recorded that live attenuated vaccines, its strains come from fowlpox of chicken or pigeons has been used to prevent fowlpox disease in susceptible birds.

Paramunity inducers (PIND) from attenuated pox virus directly activate and regulate the paraspecific (innate) immune system. Pox viruses are good paramunity inducers. In passaging they very early loose the specific immunizing epitopes whereas the phylogentic older epitopes are conserved and hence the paraspecific cytokine regulating function is retained (Brames and Mayr 2006).

Table (2), showed good body weight in different vaccinated groups; which show high body weight in the groups vaccinated with pigeon pox vaccine especially in the groups which were taken a booster dose of PP as group 5 even after vaccination in the contrast the groups which were vaccinated with Avian influenza alone as group 4or the control, that agree with Okwor et al., (2012), who founded that the performance of the bird as measured by average weight gain was $775 \pm 2.89 \mathrm{gm}$ in vaccinated group with avipox vaccine which were significantly higher $(\mathrm{P}<0.05)$ than unvaccinated group which it's average weight gain was $570 \pm 11.54 \mathrm{gm}$.

The representing results in table (3) showed that the SNT against FPV was protective from 15 to 21 days of age in all PPV vaccinated groups and still to the end of experiment and it agreed with Michael $\boldsymbol{e t}$ al., (1986) who recorded that the pigeon pox vaccinated chicks at one and three week old given 80$90 \%$ protection when challenged 4 week after vaccination. Hala, et al., (2008) recorded that the PPVV act as immunostimulant to counter act the immunesuppression effect of the intermediate strains of IBDV vaccines. This agreed with the results in table (4) which show increasing of the immune response against AIV not less than HI10 $\log 2$ titer in all groups that vaccinated with PPV previously $3^{\text {rd }}$ week post vaccination especially in groups 3,5,9 and 10 which were boosted after 35 days.

This high antibody titer was continuously high till the end of this study at 24 week post vaccination in all groups that was not less than $9 \log 2$ titer at the end of the study. While in groups 3,5,9 and 10 that primeboost with the two vaccines together the HI antibody titer were high till 8 weeks post vaccination not less than $10 \log$ titer in groups 9 and 10 and this agreed with Steensels et al., (2008) who reported that the prime-boost vaccination scheme was shown to be immunogenic in 1 day old.

Previous studies showed a correlation between serologic response and protection against mortality and viral shedding (Kumar et al., 2007). Also, the OIE terrestrial manual suggests that the protection from mortality and protection from virus shedding depend on serological potency (OIE, 2012). Kumar $\boldsymbol{e t}$. al., (2007) showed that low antibody titers of 10 to 40 prevent mortality with no viral shedding; while titers greater than 40 prevent mortality and reduce shedding .Previous evidence showed that serological titers are associated with protection when the challenge and vaccine viruses are genetically and antigenically closely related. The presence of $\mathrm{HI}$ antibodies predicted protection in the field as well (Swayne et al., 2015).

The results were also confirmed by Kemal Karaca et al., (2005) who reported that poxvirus vectored influenza vaccines should be considered as an alternative in the development of specific influenza vaccines. The antibody responses were detected as early as 1 week after the first vaccination, mounted a booster response to the second vaccination that cross- 


\section{Effectiveness Of The Pigeon Pox Vaccine ......}

reacted with a recent highly pathogenic Asian H5N1 isolate.

Full protection against clinical signs and shedding was induced by the different vaccination schemes. However, the broadest antibody response and the lowest antibody increase after challenge were observed in thegroup whose immune system was primed with the fowlpox vectoredvaccine and boosted with the inactivated vaccine, suggesting that this primebooststrategy induced optimal immunity against H5N1 and minimal viral replication afterchallenge. In addition, this prime-boost vaccination scheme was shown to be immunogenic in 1dayold (Steensels et al., 2008).

The use of a prime-boost vaccination on a routine basis provides a sufficient level of protection to minimize highly pathogenic avian influenza (HPAI) virus shedding and decrease the viral load, leading to a successful and effective HPAI virus control strategy.Prime-boost vaccination with a fowlpox vector and an inactivated avian influenza vaccine is highly immunogenic when challenged with Asian H5N1 HPAI (Boehringer, 2017).

Following challenge with HPAIV, all chickens vaccinated with AI inactivated vaccine with PPV were protected, while the chickens vaccinated with either the unaltered parent pox vaccine virus or unvaccinated controls experienced $100 \%$ mortality following challenge. This protection was accompanied by the high levels of specific antibody to the respective components showed that pigeon pox and avian influenza could be a potential vaccine to replace current inactivated vaccines for preventing $\mathrm{AI}$ and this agreed with Qiao et al., (2003).

The results in table (5) agreed with Ali et al., (2019) Challenged SPF chickens showed significant decreases in the virus shedding titers up to $<3 \log 10$ compared to challenge control chickens. detected No virus shedding was 6 "days post-challenge" in all vaccinated challenged groups, and with Niqueux $\boldsymbol{e t}$ al., (2013), who reported that the reduction of oropharyngeal shedding levels was also constantly observed from the onset of the followup at 2.5 or three days post-infection in vaccinated ducks compared to unvaccinated controls, and was significantly more important for vFP89+vNDV-H5 vaccination. Also confirmed with Ellis et al., (2006) who said that vaccination with commercially available inactivated vaccines based on avian influenza virus subtype $\mathrm{H} 5$ can confer clinical protection and reduce virus shedding after infection.
Table (6) showed that Pigeon pox virus and AIV was evaluated for its ability to protect chickens against intramuscular challenge with a lethal dose of highly pathogenic (HP) AIV; Following challenge 28 days later with HPAIV, all chickens vaccinated were protected, especially in groups 4, 5 and 10were with protection percent $95 \%$, while unvaccinated controls experienced $100 \%$ mortality following challenge. This protection was accompanied by the high levels of specific antibody to the respective components showed that pigeon pox and avian influenza could be a potential vaccine to replace current inactivated vaccines for preventing AI. This is in agreement with Qiao et al., (2003).

\section{CONCLUSION}

In conclusion, full protection against clinical signs and shedding of avian influenza virus was induced by the different vaccination schemes; However, the present work is demonstrating the high efficacy of the successive administration pigeon pox vaccine, the broadest antibody response and the lowest antibody increase after challenge were observed in the groups 5 and 10 whose immune system was primed with the PPV vaccine and boosted with the PPV and inactivated AI vaccine also the group that primed with both vaccines and boosted with them together gave high immune response that continued to the end of this study; while the group 10 is the preferable one because in which we applied both PP and AI at the same time in the primary and booster vaccinations, suggesting that this prime-boost strategy induced optimal immunity against $\mathrm{H} 5 \mathrm{~N} 1$ and minimal viral replication after challenge.

\section{Declaration of Competing interest}

On behalf of all authors, I hereby declare that no conflict of interest may interfere with the publication of the manuscript.

\section{REFERENCES}

ALI A., MARWA SAFWAT, WALID H. KILANY, ABDOU NAGY, AWAD A. SHEHATA, MOHAMED A. ZAIN EL-ABIDEEN,AL. HUSSIEN M. DAHSHAN1 AND ABDEL-SATAR ARAFA A. 2019. Combined H5ND inactivated vaccine protects chickens against challenge by different clades of highly pathogenic avian influenza viruses subtype $\mathrm{H} 5$ and virulent Newcastle disease virus. Veterinary World, EISSN: 2231-0916 . Vol 12(1): 97-105.

ALLAN, W.H, J.E. LANCASTER AND TOTH, B.1978. Newcastle disease vaccines their production and use. FAO Animal Production and Health Seriesho. 10 FAO.Rome. Italy.

ANON 1971. Methods for examining poultry biologics and for identification and quantifying avian pathogens. 
Newcastle disease, US National Academy of sciences, Wasinghton DC, pp: 66.

BEARD, C. W., SCHNITZLEIN, W. M. AND TRIPATHY, D. N. 1991. Protection of chickens against highly pathogenic avian influenza virus (H5N2) by recombinant fowlpox viruses. Avian Dis, 35, 356-359.

BOEHRINGER 2017. Prime-Boost Vaccination in Egypt: Field Experiences. Information from the Avian Flu Forum hosted by Boehringer. By ludmila starostina. $5 \mathrm{~m}$ Publishing, England.

BOSSINGER, T.R.; WINTERFIELD, R. W.; FELDMAN, D.S. AND DHILLON, A. S. 1982. Psittacine pox virus: virus isolation and identification, transmission and crosschallenge studies in parrots and chickens. Avian Dis, 26: 437 - 444.

BRAMES, H. AND MAYR A. 2006. Safety and Effectiveness of Paramunization in Import Reptiles. Diss. Med. Vet., Munchen. Qmvet.de. researchgate. Net.

BRANDLY, C. A. Y. AND DUNLOP G. L. 1939. Studies on certain filterable viruses. II Immunization against fowl pox with fowl pox and pigeon pox viruses cultivated in vivo and in vitro. J. Amer. Vet. Med. Ass., 95, 430-349.

BUBLOT M., PRITCHARD N., SWAYNE DE., SELLECK P., KARACA K., SURAREZ DL., AUDONNET JC, AND MICKLE TR. 2006. Development and use of fowlpox vectored vaccines for avian influenza. Ann N Y Acad Sci. 1081:193201.

BYC SUPPORT 2012. 49 Comments/ 243.9K/ Injuries, Diseases, and Cures.

COTTRAL, G.E. 1978. pox viruses. In a journal of standardized methods for veterinary microbiology. Ed. E.g. cottral corner university press (Itha-ca and London), pp 273-291.

DALLING, T. 1933. Recent progress in the investigation of poultry diseases. Vet. J., 89, 441-449.

DIENER, K. R., E. L. LOUSBERG, E. L. BEUKEMA, A. YU, P. M. HOWLEY, M. P. BROWN, AND J. D. HAYBALL 2008. Recombinant fowlpox virus elicits transient cytotoxic $\mathrm{T}$-cell responses due to suboptimal innate recognition and recruitment of $\mathrm{T}$ cell help. Vaccine, 26:3566-3573.

EGYPTIAN STANDARD PROTOCOL 2017. Egyptian standards regulation for evaluation of veterinary vaccinations $3^{\text {rd }}$ edition.

ELLIS TM, SIMS LD, WONG HK, WONG CW, DYRTING KC. AND CHOW KW2006. Use of avian influenza vaccination in Hong Kong. DevBiol (Basel). 124:133-43.

GIOTIS E. S. AND 2019 SKINNER M. A. 2019. Spotlight on avian pathology: Fowlpox virus. Avian pathology 48(2), 87-90.

GOLDHAFT, T.M. 1956. A new method of application of pigeon pox vaccine. J. Amer. Vet. Med, Ass., 128:596-601.

GOTTSTEIN, Z.; CIGLAR G. I.; HORVATEK, D.; PRUKNER-RADOVCIC, E.; CAJAVEC, S. AND MAZIJA, H. 2004. Safety and immunogenicity of pigeon pox virus vaccine applied to newly hatched chickens by means of nebulisation, In : Book of
Abstracts XXII World Poultry Congress, Istanbul, Turkey.

GRAHAM, R. AND BRANDLY E.H. 1940. Immunization against pox in domestic fowl. Illinois Agr Exp. Sta. Bull., 470, 75pp

HALA, M. E.; MICHAEL, A. I. AND NAMAA, A. M. 2008. Immunomodulation effect of pigeon pox vaccine in chicken vaccinated with IBDV strains. Proceedings of the Middle East \& North Africa (MENA) Region Animal Wealth Research Conference. Future of animal wealth, Cairo International Convention Center, Egypt, ,pp. 140-148.

HY-LINE 2019. Copyright 2019 Hy-Line International Fowl Pox Prevention Website design and development bySpindustry Digital, Des Moines, Iowa.

JOHNSTON J. B. AND GRANT MCFADDEN 2003 MINIREVIEW: Poxvirus Immunomodulatory Strategies: Current Perspectives. Journal of Virology, p. 6093-6100 Vol. 77, No. 11.

KUMAR M, CHU HJ, RODENBERG J, KRAUSS S. AND WEBSTER RG. 2007. Association of serologic and protective responses of avian influenza vaccines in chickens. Avian Diseases, 51:481-3.

LEE D., YUK S., PARK J., KWON J., ERDENE T., NOH J., YU S.HWANG S., LEE S. AND SONG C. 2013. Innate immune response gene expression profiles in specific pathogen free chickens infected with avian influenza virus subtype H9N2.Springer.BioChip Journal; Vol.7.issue 4, PP 303-398.

MESEKO C. A., SHITTU I. A., AND AKINYEDE O. 2012. Seroprevalence of Fowl Pox Antibody in IndigenousChickens in Jos North and South Council Areas ofPlateau State, Nigeria: Implication for Vector Vaccine 2International Scholarly Research NetworkISRN Veterinary ScienceVolume 2012, Article ID 154971, 4 pages.

MICHAEL A.; NASSAR N.I. AND EL SABBAGH A.1986. Combined vaccination with pigeon and fowl pox vaccines. Second Sci. Con., Fac. Vet.Med., Assiut Univ. AssiutVet.Med. J. Vol. 16, No. 31. P:365-380.

MICHEL B, NIKKI P, DAVID E. S, PAUL S, KEMAL K, DAVID L. S, JEAN-, AND THOMAS R. M .2006. Development and Use of Fowlpox Vectored Vaccines for Avian Influenza. 254, rue Marcel M'erieux, 69007 Lyon, France. Voice: 33-4-72725973; fax: 33-4-7272-3316.

NIQUEUX E. ,GUIONIE O., AMELOT M. AND JESTIN V. 2013. Prime-boost vaccination with recombinant H5-fowlpox andNewcastle disease virus vectors affords lasting protection in SPFMuscovy ducks against highly pathogenic H5N1 influenza virus. Vaccine.28;31 (38) :4121-8. doi: 10.1016/j.vaccine.2013.06.074. Copyright (C) 2013 Elsevier Ltd. All rights reserved.

OIE. 2012. Sheep pox and goat pox. In: Terrestrial Animal Health Code. World Organization for Animal Health, Paris, France.

OIE.2016. OIE Terrestrial manual, chapter 3.3.4Avian influenza. P:821-843.

OIE. 2019. OIE Terrestrial manual, chapter 3.3.10 Fowlpox. 906-913. 
OKWOR, E.C., EZE, D.C. AND AGBO, I.C. 2012. The Effects Of Vaccination, Antibiotic And Vitamin therapy on some clinical parameters associated with natural outbreak of fowpox in chickens. J. of Vet. Med. And Anim. Heal., Vol. (9), PP. 136-139.

PAOLETTI, E. 1990. Poxvirus recombinant vaccines. Ann. N. Y. Acad. Sci. 590:309-325.

QIAO CL., YU KZ., JIANG YP, JIA YQ., TIAN GB., LIU M., DENG GH. AND TANG XY. 2003. Protection of chickens against highly lethal H5N1 and H7N1 avian influenza viruses with a recombinant fowlpox virus co-expressing $\mathrm{H} 5$ haemagglutinin and N1 neuraminidase genes. Avian Pathol. 32(1):25-32.

RADAELli, A., C. ZANOTTO, G. PERLETTI, V. ELLI, E. VICENZI, G. POLI, AND C. DE GIULIMORGHEN. 2003. Comparative analysis of immune responses and cytokine profiles elicited in rabbits by the combined use of recombinant fowlpox viruses, plasmids and virus-like particles in primeboost vaccination protocols against SHIV. Vaccine, 21:2052-2064.

REED, L.J. AND MUNECH, H. 1938. A simple method of estimating fifty percent end points. Am. J. Hyg, 27:493-497.

RICHARD-MAZET A., GOUTEBROZE S., LE GROS F-X., SWAYNE D.E. AND BUBLOT M. 2016. Immunogenicity and efficacy of fowlpox-vectored and inactivated avian influenza vaccines alone or in a prime-boost schedule in chickens with maternal antibodies. Vet. Res., 45:107.

SELIM, A., ERFAN, A., HAGAG, N., ZANATY, A., SAMIR, A.H., SAMY, M., ABDELHALIM, A. ARAFA, A.A., SOLIMAN, M., SHAHEEN, M., IBRAHEEM, E., MAHROUS, I., HASSAN, M., AND NAGUIB, M. 2017. Highly pathogenic avian influenza virus (H5N8) Clade 2.3.4.4 infection in migratory birds, Egypt. Emerg. Infect. Dis., 23(6): 1048-1051.

SIDDIQUE, A. B., HOSSAIN, F. M. A. ANDZINNAHM. A. 2011. Determination of host specificity of pigeon pox and fowl pox viruses isolated from a field outbreak. Bulgarian Journal of Veterinary Medicine, 14, No 4, 209-214.

STEENSELS, M., BUBLOT, M., VAN S., BORM, B. , DE VRIESE, J. L., RICHARD-MAZET, A., CHANAVAT- BIZZINI, S., DUBOEUF, M., LE GROS, F.-X.AND BERG, T. 2008. Search ScienceDirecthttps://doi.org/10.1016/j.vaccine..11.04 4. Outline Purchase PDFP urchaseExport AdvancedGet rights and content.

SWAYNE DE, SUAREZ DL, SPACKMAN E, JADHAO S, DAUPHIN G, KIM-TORCHETTI M. 2015. Antibody titer has positive predictive value for vaccine protection against challenge with natural antigenic-drift variants of $\mathrm{H} 5 \mathrm{~N} 1$ high-pathogenicity avian influenza viruses from Indonesia. Journal of Virology. 89:3746-62.

TASLIMA, A., SHAHIDUR M., PAUL N., KAFI, A., SHIL, N. ANDSIDDIQUE M. 2008. Persistence of Maternally Derived Antibody in selected group of chicks to fowl pox virus. Bangladesh J. Micro., Vol. 25(1):57-59.
TAYLOR, J., TRIMARCHI, C., WEINBERG, R., LANGUET, B., GUILLEMIN, F., DESMETTRE, P.AND PAOLETTI, E. 1991. Efficacy studies on a canarypox-rabies recombinant virus. Vaccine, 9:190193.

TAYLOR, J., WEINBERG， R., LANGUET, B., DESMETTRE, P. AND PAOLETTI, E. 1988. Recombinant fowlpox virus inducing protective immunity in non-avian species. Vaccine, 6:497-503.

TAYLOR，J.，WEINBERG， R.，TARTAGLIA， J., RICHARDSON, C., ALKHATIB, G., BRIEDIS, D., APPEL, M., NORTON, E. AND PAOLETTI, E. 1992. Non replicating viral vectors as potential vaccines: recombinant canarypox virus expressing measles virus fusion $(\mathrm{F})$ and hemagglutinin (HA) glycoproteins. Virology, 187, 321-328.

TRIPATHY D.N. AND REED W.N. 2003. Disease of Poultry. $11^{\text {th }}$ ed. Pox ,p.253-269.Blackwell Publishing Ames, Iowa.

TRIPATHY D.N. AND REED W.N. 2008. Disease of Poultry. $12^{\text {th }}$ ed. Pox ,p.291-308.Blackwell Publishing Ames, Iowa.

TUMPEY T. M., KAPCZYNSKI D. R. AND SWAYNE D.E. 2004. Comparative susceptibility of chickens and turkeys to avian influenza A H7N2 virus infection and protective efficacy of a commercial avian influenza H7N2 virus vaccine. Avian Dis., 48167176.

WANG, J.; MEERS, J.; SPRADBROW, P. B. AND ROBINSON, W. F. 2006. Evaluation of immune effects of fowl pox vaccine strains and field isolates. Vet. Microbial, 116: $106-119$.

WEBSTER, R. G., TAYLOR, J., PEARSON, J., RIVERA, E. AND PAOLETTI, E. 1996. Immunity to Mexican H5N2 avian influenza viruses induced by a fowl pox-H5 recombinant. Avian Dis40, 461-465.

WEBSTER, S. J., DUNACHIE, D. P., VUOLA, S., BERTHOUD, J. M., KEATING,T., LAIDLAWS., MCCONKEY, S. M., POULTON, I., ANDREWS,L., L. ANDERSEN, L., BEJON, P., BUTCHER, G., SINDEN,R. , SKINNER,M. A. , GILBERT, S. C. AND HILL, A. V. 2005. Enhanced $\mathrm{T}$ cell-mediated protection against malaria in human challenges by using the recombinant poxviruses FP9 and modified vaccinia virus Ankara. Proc. Natl. Acad. Sci. USA 102:4836-4841.

WELI S.C AND TRYLAND M. 2011. Avipoxviruses; infection biology and their use as vaccine vectors. Review. Virology Journal. 8:49.

WHO: WORLD HEALTH ORGANIZATION 2008. $\mathrm{H} 5 \mathrm{~N} 1$ avian influenza.timeline of major events, Available from http://www.who.int/csr/disease/ avian_influenza/Timeline 07 Aug27.pdf.

How to cite this article:

Christine A. Mikhael and Nada, A. Fathy, 2019. Effectiveness Of The Pigeon Pox Vaccine On The Chicken Vaccinated With Avian Influenza Vaccine. Journal of Applied Veterinary Sciences, 4(2): 62-70. DOI : https://dx.doi.org/10.21608/javs.2019.62659 